\title{
Documentation of ethical conduct of human subject research published in Saudi medical journals
}

\author{
E.A. Al-Gaai, ${ }^{7}$ M.M. Hammami ${ }^{7}$ and M. Al Eidan ${ }^{7}$
}

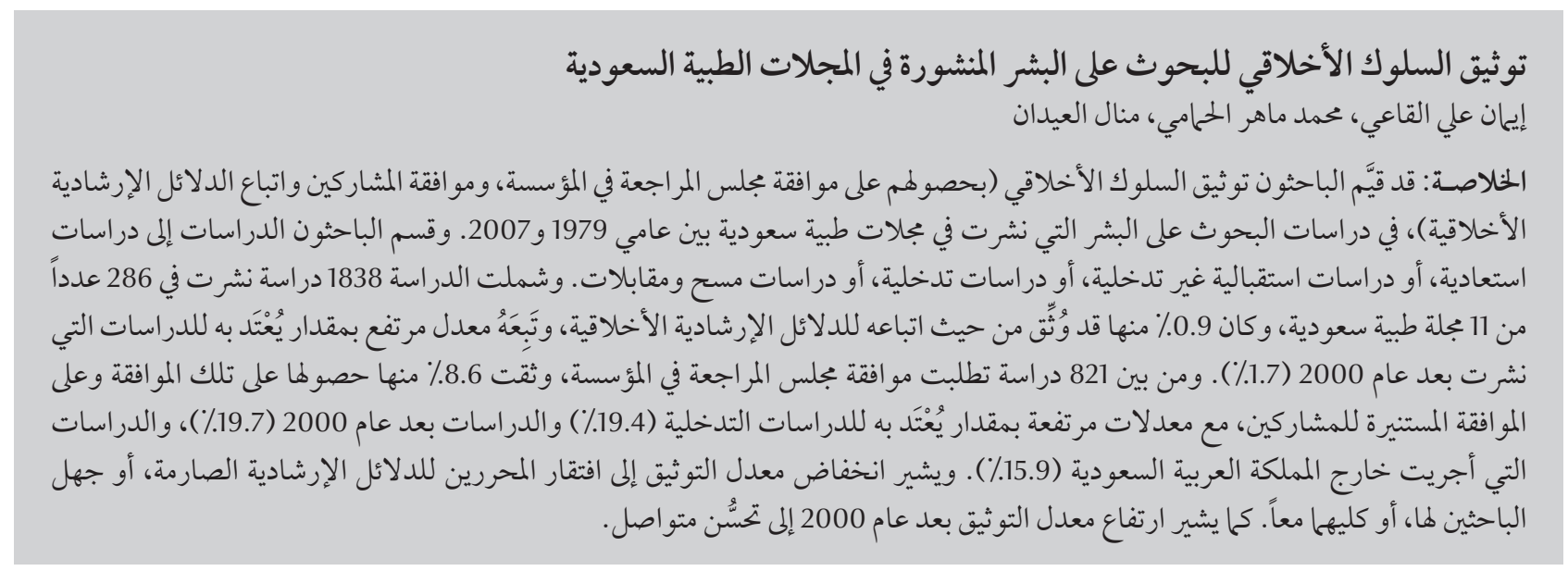

ABSTRACT We evaluated the documentation of ethical conduct (obtaining institutional review board approval and consent and following ethical guidelines) of human subject research studies published in Saudi Arabian medical journals between 1979 and 2007. Studies were classified as retrospective, prospective noninterventional, interventional or survey/interview. Of 1838 studies published in 286 journal issues of 11 Saudi Arabian medical journals, only $0.9 \%$ documented the ethical guidelines followed, with a significantly higher rate for studies published after year 2000 (1.7\%). Of 821 studies requiring institutional review board approval, 8.6\% documented obtaining the approval and informed consent, with a significantly higher rate for interventional studies (19.4\%), post-year 2000 studies (19.7\%) and studies performed outside Saudi Arabia (15.9\%). The low documentation rate suggests editor's lack of rigor and/or investigators' ignorance of guidelines. The higher documentation rate after year 2000 suggests an ongoing improvement.

Justification du respect des règles éthiques dans la conduite de recherches impliquant des personnes publiées dans des revues médicales saoudiennes

RÉSUMÉ Nous avons évalué les pièces à l'appui du respect de ces règles (obtention de l'approbation d'un comité d'examen institutionnel et d'un consentement, et observation des directives éthiques) dans la réalisation d'études de recherche impliquant des personnes publiées dans des revues médicales saoudiennes entre 1979 et 2007. Les études ont été classées selon leur type : rétrospectives, prospectives non interventionnelles, interventionnelles ou enquêtes/entretiens. Sur 1838 études publiées dans 286 numéros de 11 revues médicales saoudiennes, seules $0,9 \%$ apportaient la justification du respect des directives éthiques. Ce taux est supérieur (1,7\%) pour les études publiées après 2000. Sur 821 recherches nécessitant l'approbation d'un comité d'examen institutionnel, 8,6\% disposaient de la documentation prouvant son obtention et de celle d'un consentement éclairé. Ce taux est nettement supérieur pour les études interventionnelles (19,4\%), les études postérieures à l'année 2000 (19,7\%), et celles menées hors de l'Arabie saoudite (15,9\%). Le faible taux d'études pouvant justifier le respect des règles éthiques suggère que le rédacteur manque de rigueur et/ou que les chercheurs ignorent les directives. La hausse du taux après l'année 2000 est le signe qu'une amélioration est en cours.

${ }^{7}$ Centre for Clinical Studies and Empirical Ethics, King Faisal Specialist Hospital and Research Centre, Riyadh, Saudi Arabia (Correspondence to M.M. Hammami:muhammad@kfshrc.edu.sa).

Received: 11/04/11; accepted: 26/06/11 


\section{Introduction}

Investigators have a primary responsibility to safeguard the rights and welfare of subjects participating in research studies. This responsibility is shared by the institutions where the studies are conducted and the editors of the journals publishing the results [1]. The available means of protection of human subjects in research include obtaining informed consent and approval of the study proposal and consent form by an independent institutional review board (IRB) $[1,2]$. Written informed consent is the default standard for any research involving human subjects $[1,2]$. However, it can be waived by the IRB in well-defined circumstances [1]. Consent for publication is required when it is necessary to publish information that identifies individuals [1]. Ethical requirements to protect human subjects apply to a much broader range of research than many investigators may realize. For example, it applies to research that uses individually identifying private information even if the information was not specifically collected for the study in question, to research on bodily materials, cell lines or DNA samples that can be associated with an individual source even if the investigator him/ herself did not collect these materials, and to research on left-over diagnostic specimens [1].

The International Committee of Medical Journal Editors (ICMJE) established its first guidelines for manuscript submission in 1978 [3]. Its 1981 edition required authors to indicate procurement of IRB approval [4], the 1991 edition added the requirement to indicate if informed consent was obtained [5] and the latest 2004 edition stated that authors should indicate whether the procedures followed were in accordance with the ethical standards of the responsible committee and with the Helsinki Declaration [6]. While most international peer-reviewed journals subscribe to these guidelines [7], there is evidence that these guidelines are not universally followed [8-13].

There are 64 medical journals published in Saudi Arabia (scientific journals, bulletins and newsletters), of which 20 are in the English language [14]. The compliance of Saudi medical journals with ICMJE guidelines has not been studied before. We reviewed documentation of compliance with ethical guidelines in human subject research studies published in 11 Saudi medical journals between 1979 and 2007 and explored the factors associated with such documentation.

\section{Methods}

\section{Sample}

The sample was original research studies using human subjects published between 1979 and 2007 in 286 journal issues of 11 Saudi medical journals ( $\mathrm{Ta}$ ble 1), accessible electronically in full or available at the authors institution's medical library. A human subject was defined as an individual about whom an investigator obtains data through interventional or interaction with the individual or identifiable private information [1].

\section{Procedure}

Using a structured data collection tool, the research studies were classified into: retrospective studies (based on pre-existing medical records or biological samples), prospective non-interventional studies (based on medical records or biological samples), interventional studies, surveys or interviews. They were also classified into studies requiring both IRB approval and informed consent (interventional studies, prospective medical records or

\begin{tabular}{|c|c|c|c|c|c|}
\hline \multirow[t]{2}{*}{ Journal title (launch year) } & \multirow{2}{*}{$\begin{array}{c}\text { Journal issues } \\
\text { per year } \\
\text { No. }\end{array}$} & \multirow{2}{*}{$\begin{array}{c}\text { Original } \\
\text { studies per } \\
\text { journal issue } \\
\text { No. }\end{array}$} & \multirow[t]{2}{*}{$\begin{array}{l}\text { Review } \\
\text { period }\end{array}$} & \multicolumn{2}{|c|}{$\begin{array}{l}\text { Human subject } \\
\text { research studies } \\
\text { identified }\end{array}$} \\
\hline & & & & No. & $\%$ \\
\hline Annals of Saudi Medicine (1985) ${ }^{\mathrm{a}}$ & 4 (before 1988) 6 (1988-) & 6 & 1981-2007 & 339 & 18.4 \\
\hline Annals of Thoracic Medicine (2006) & 2 (2006) 4 (2007-) & 4 & 2006-07 & 23 & 1.3 \\
\hline Journal of Family and Community Medicine (1994) & 2 (1994-99) 3 (2000-) & 4 & 1997-2007 & 133 & 7.2 \\
\hline Journal of the Saudi Heart Association (1998) & $2-3$ & 5 & 1995-2007 & 53 & 2.9 \\
\hline Neurosciences (2000) & 4 & 6 & $2000-07$ & 141 & 7.7 \\
\hline Pan Arab Journal of Neurosurgery (1997) & 2 & 3 & 1999-2001 & 6 & 0.3 \\
\hline Saudi Dental Journal (1989) & 3 & $4-6$ & 1984-2007 & 136 & 7.4 \\
\hline Saudi Journal of Anaesthesia (2007) & 3 & 3 & 2007 & 9 & 0.5 \\
\hline Saudi Journal of Gastroenterology (1995) & 3 & 6 & 2004-2007 & 40 & 2.2 \\
\hline Saudi Medical Journal (1979) & 12 & 8-11 & 1979-2007 & 943 & 51.3 \\
\hline Saudi Pharmaceutical Journal (1993) & 4 & 5 & 2003-06 & 15 & 0.8 \\
\hline
\end{tabular}

${ }^{a}$ From 1980-84 it was entitled KFSH\&RC Medical Journal, in 1985 it became the Annals of Saudi Medicine. 


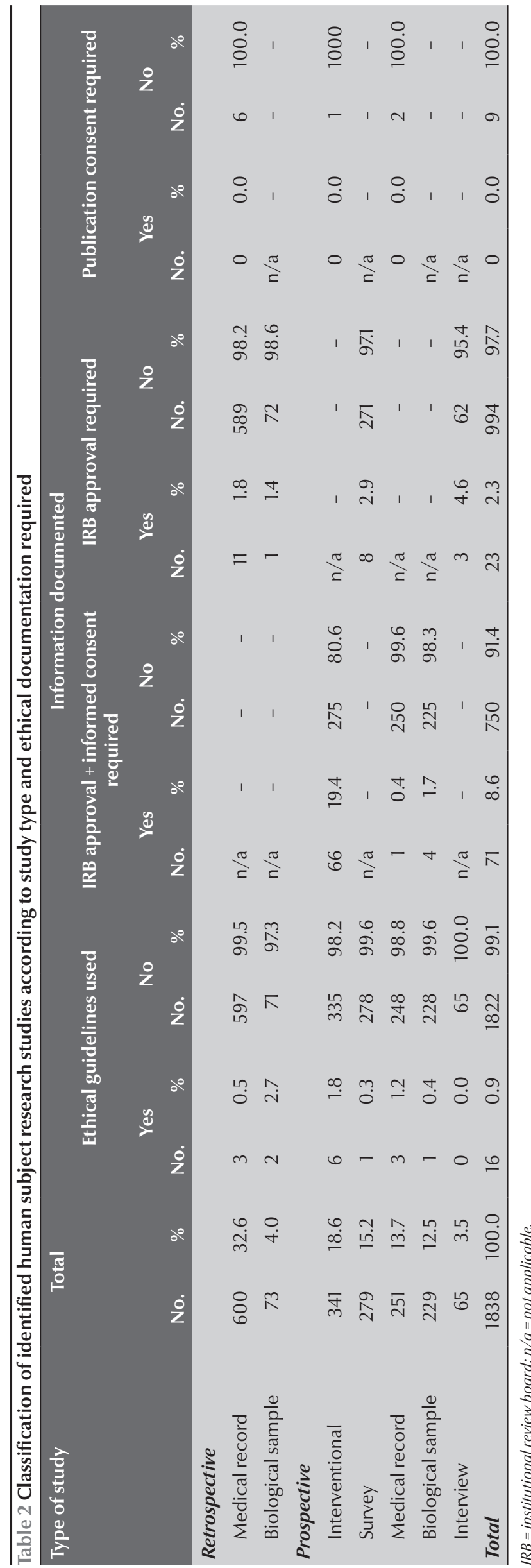

biological samples-based studies) or studies requiring IRB approval only, in which informed consent could have been possibly waived by the IRB (retrospective medical records or biological samples-based studies, surveys and interviews).

The following information was also collected for each study: publication year, country where the study was performed (Saudi Arabia or other country), publication of individually identifying information (and documentation of consent to publish such information) and the presence of a statement about the ethical guidelines that were followed. Uncertainties about the classifications were resolved by discussion among the authors.

This study was reviewed and approved by the research ethics committee of the author's institution.

\section{Statistical analysis}

The data were analysed using SPSS for Windows, version 13.0. The chi-squared test was used to study associations. All reported $P$-values are 2-sided.

\section{Results}

We identified 1838 human subject research studies that were published in English between 1979 and 2007 in 286 journal issues of 11 Saudi medical journals (Table 1). There were 383 (20.9\%) published from 1979-89, 612 (33.3\%) from 1990-99, and 843 (45.9\%) from 2000-07. Most (1369, 74.5\%) were conducted in Saudi Arabia and 469 (25.5\%) outside Saudi Arabia. One-third $(673,36.6 \%)$ were retrospective and $1165(63.4 \%)$ were prospective.

\section{Documentation of ethical guidelines followed}

Only $16(0.9 \%)$ of the 1838 studies reported the ethical guidelines that had been followed (Table 2). The type of study was not associated with the documentation rate $(P=0.16)$. There was a significant association, however, between documentation rate and year of publication ( $1.7 \%$ for studies published in $2000-07,0.3 \%$ for studies published in 1990-99, and 0\% for studies published in 1979-89) $(P=0.003)$ (Table 3). The location of study was not associated with the documentation rate $(P=$ 0.26) (Table 3 ).

\section{Studies requiring both IRB approval and informed consent}

A total of 821 studies were judged to require both IRB approval and informed consent; 71 (8.6\%) documented 


\begin{tabular}{|c|c|c|c|c|c|c|c|c|c|c|c|c|c|c|}
\hline \multirow[t]{4}{*}{ Period/location } & \multirow{3}{*}{\multicolumn{2}{|c|}{ Total }} & \multicolumn{12}{|c|}{ Information documented } \\
\hline & & & \multicolumn{4}{|c|}{ Ethical guidelines used } & \multicolumn{4}{|c|}{$\begin{array}{l}\text { IRB approval }+ \text { informed } \\
\text { consent required }\end{array}$} & \multicolumn{4}{|c|}{ IRB approval required } \\
\hline & & & \multicolumn{2}{|c|}{ Yes } & \multicolumn{2}{|c|}{ No } & \multicolumn{2}{|c|}{ Yes } & \multicolumn{2}{|c|}{ No } & \multicolumn{2}{|c|}{ Yes } & \multicolumn{2}{|c|}{ No } \\
\hline & No. & $\%$ & No. & $\%$ & No. & $\%$ & No. & $\%$ & No. & $\%$ & No. & $\%$ & No. & $\%$ \\
\hline \multicolumn{15}{|l|}{ Publication period } \\
\hline $1979-89$ & 383 & 20.8 & 0 & 0.0 & 383 & 100.0 & 0 & 0.0 & 211 & 100.0 & 1 & 0.6 & 171 & 99.4 \\
\hline 1990-99 & 612 & 33.3 & 2 & 0.3 & 610 & 99.7 & 4 & 1.5 & 266 & 98.5 & 1 & 0.3 & 341 & 99.7 \\
\hline 2000-07 & 843 & 45.9 & 14 & 1.7 & 829 & 98.3 & 67 & 19.7 & 273 & 80.3 & 21 & 4.2 & 482 & 95.8 \\
\hline \multicolumn{15}{|l|}{ Study location } \\
\hline Outside Saudi Arabia & 469 & 25.5 & 6 & 1.3 & 463 & 100.0 & 40 & 15.9 & 211 & 84.1 & 8 & 3.7 & 210 & 96.3 \\
\hline Inside Saudi Arabia & 1369 & 74.5 & 10 & 0.7 & 1259 & 92.0 & 31 & 5.4 & 539 & 94.6 & 15 & 1.9 & 784 & 98.1 \\
\hline
\end{tabular}

IRB = institutional review board.

obtaining both. Documentation rate was associated with study type $(P<$ 0.001 , with the highest rate for interventional studies) (Table 2). It was also associated with year of publication (19.7\% for 340 studies published in 2000-07, $1.5 \%$ for 270 studies published in 1990-99 and 0\% for 211 studies published in 1979-89) $(P<0.001)$ and study location (15.9\% for 251 studies conducted outside Saudi Arabia versus $5.4 \%$ for 570 studies conducted in Saudi Arabia) $(P<0.001)($ Table 3$)$.

\section{Studies requiring IRB approval only}

Out of 1017 studies that were judged to require IRB approval only $23(2.3 \%)$ had documented obtaining it (Table 2). Documentation rate was not associated with study type $(P=0.42)$ (Table 2$)$ or with location $(P=0.12)$ (Table 3$)$. It was associated, however, with year of publication ( $4.2 \%$ for 503 studies published in 2000-07, 0.3\% for 342 studies published in 1990-99 and 0.6\% for 172 studies published in 1979-89) $(P<0.001)$ (Table 3$)$.

\section{Documentation of consent to publish}

None of the 9 studies containing individually identifying information documented that they had obtained consent to publish.

\section{Discussion}

We found that the documentation rate of ethical conduct in human subject research studies published in Saudi medical journals was exceedingly low. Although the observed rate could be artificially low because of convenient sampling, inclusion of studies published since 1979 and a high percentage of non-interventional studies, we think that the true rate is low; the journals reviewed represent $55 \%$ of Saudi medical journals published in English, and the rate of documentation for IRB approval and informed consent remained low at $19.7 \%$ for studies published after 2000 and $19.4 \%$ for interventional studies. For comparison, the documentation rate of obtaining informed consent and IRB approval was $62 \%$ and $49 \%$ respectively for clinical trials published in 1993-94 in 4 Western gerontology journals [8], and $72.6 \%$ and $69.4 \%$ for clinical trials and other studies published in 3 Western journals of paediatrics in January to December 2000 [9]. A statement about IRB approval or informed consent was documented in $61 \%$ of child health studies of all designs (97\% for clinical trials) published in 1999 [10]. Finally, the documentation rate of obtaining both informed consent and
IRB approval was $64 \%$ for clinical trials published in 6 Western physiotherapy journals in 1996-2001 [11].

The low overall documentation rate could be due to failure to report (rather than obtain) IRB approval/ informed consent, unavailability of an IRB at the investigator's institution or the investigators' ignorance about when IRB approval/informed consent are required. The later may explain the lower documentation rate for non-interventional studies and the higher documentation rate for studies conducted outside Saudi Arabia, which may be related to investigators' training or participation in multicentre or industry-sponsored studies. This issue was not explored in our study. Other potential causes include failure on the part of peer reviewers and journal editors due to lack of capacity or overload. The latter is unlikely given the reasonable number of research articles published per year.

We found a significant increase in the documentation rate after year 2000 , consistent with previous studies $[12,13]$. The documentation rate of informed consent and IRB approval respectively was $74 \%$ and $69 \%$ before 1997, 82\% and 82\% after 1997 [12] and $87 \%$ and $93 \%$ in 2003 for articles on clinical trials published in 5 major 
Western medical journals [13]. It is of note that a Saudi national research regulatory oversight system, the National Bioethics Committee, was established in 2001 [15].

In conclusion, the documentation rate of ethical conduct in human subject research studies published in Saudi medical journals was low, suggesting editors' lack of rigor and/or investigators' ignorance of guidelines. The lower documentation rate for non-interventional studies and for studies conducted in Saudi Arabia suggests unawareness of the scope of human subject research, whereas the higher documentation rate after year 2000 suggests an ongoing improvement.

\section{Acknowledgements}

We thank Dr Sahar Attallah for her valuable assistance in data collection.

\section{References}

1. 45 CFR 46 Protection of human subject: Subpart A. Revised January 2009 Department of Health and Humans Services [online] (http://www.hhs.gov/ohrp/humansubjects/ guidance/45cfr46.html\#subparta, accessed 2 June 2012).

2. Ethical principles for medical research involving human subjects. Revised October 2008. World Medical Association Declaration of Helsinki [online] (http://www.wma.net/ en/30publications/10policies/b3/, accessed 2 June 2012).

3. International Committee of Medical Journal Editors. Uniform requirements for manuscripts submitted to biomedical journals. Journal of the American Medical Association, 1993, 269:2282-2286.

4. International Committee of Medical Journal Editors. Uniform requirements for manuscripts submitted to biomedical journals. Annals of Internal Medicine, 1982, 96:766-771.

5. International Committee of Medical Journal Editors. Statements from the International Committee of Medical Journal Editors. Journal of the American Medical Association, 1991, 265:2697-2698.

6. Uniform requirements for manuscripts submitted to biomedical journals. Updated October 2004. Philadelphia, International Committee of Medical Journal Editors, 2004 [online] (http:// www.icmje.org/2004_urm.pdf, accessed 29 May 2012).

7. Rowan-Legg A et al. A comparison of journal instructions regarding institutional review board approval and conflict-ofinterest disclosure between 1995 and 2005. Journal of Medical Ethics, 2009, 35:74-78.
8. Rikkert MGO, ten Have HA, Hoefnagels WH. Informed consent in biomedical studies on aging: survey of four journals. British Medical Journal, 1996, 313:1117.

9. Weil E, Nelson RM, Ross LF. Are research ethics standards satisfied in pediatric journal publications? Pediatrics, 2002, 110:364-370.

10. Bauchner H, Sharfstein J. Failure to report ethical approval in child health research: review of published papers. British Medical Journal, 2001, 323:318-319.

11. Henley LD, Frank DM. Reporting ethical protections in physical therapy research. Physical Therapy, 2006, 86:499-509.

12. Yank V, Drummond R. Reporting of informed consent and ethics committee approval in clinical trials. Journal of the American Medical Association, 2002, 287:2835-2838.

13. Schroter $\mathrm{S}$ et al. Reporting ethics committee approval and patient consent by study design in five general medical journals. Journal of Medical Ethics, 2006, 32:718-723.

14. Merghalani MA. Central Medical Library in Saudi Arabia: establishment and prospective development. Cybrarians Journal, 2005, 4 (http://www.cybrarians.info/journal/en/no4/ medlib.htm, accessed 29 May 2012)

15. First regional meeting of National Bioethics Committees, Cairo 5-7 May 2007. United Nations Educational, Scientific and Cultural Organization [online document] (http://unesdoc. unesco.org/images/0015/001528/152805e.pdf, accessed 29 May 2012). 